conflicting interests now warring in Palestine. After a distinguished career as a classical scholar at Magdalene College, Cambridge, he joined the Sudan Political Service in 1905, and served in the provinces of Kordofan, Blue Nile and Khartum. During the Great War he served as political and intelligence officer with the expeditionary force which reoccupied Darfur in 1916. A successful official career culminated in the appointment of civil secretary, which he held from 1926 until 1934, on several occasions acting as governor. In the course of his service in the Sudan he became our foremost authority on the ethnology and history of the Sudanese tribes, his published works including "The Tribes of Northern and Central Kordofan" (1912), "A History of the Arabs in the Sudan" (1922) and "The Arabs of the Egyptian Sudan" (1924). For these studies he was awarded the Burton Memorial Medal of the Royal Asiatic Society in 1928. Sir Harold's onerous duties as Governor of Tanganyika have not precluded his continued interest in scientific studies, which has been directed mainly to local archæology and the foundation of a museum at Dar-es-Salaam.

\section{Memorial to Dr. Samuel Smiles (1812-1904)}

ON Saturday, December 4, a bronze tablet to the memory of Samuel Smiles was unveiled at Zion School, Leeds, by Sir James Baillie, vice-chancellor of the University of Leeds. In the course of his speech Sir James said : "Smiles had a singularly sane outlook on human life and a remarkable grasp of the simple elementary principles on which human society ultimately rests. He made himself eminent in his spare time-what we should now call his leisure moments, at the end of busy days. Part of his spare time in Leeds he gave to those who attended Zion School." Smiles's first book, entitled "Physical Education", was published in 1837 at his own expense and reprinted in 1905. Messrs. John Murray published in 1905 his "Autobiography", which contains a copy of his portrait, by Sir George Reid, in the National Portrait Gallery, and in 1857 "Life of George Stephenson", which is an engineering classic. The latter arose from his meeting Stephenson at the opening of the Leeds and Derby railway, later absorbed by the Midland. He collected material during week-ends by interviewing people on Tyneside who knew of the early work, and also he received information from Robert Stephenson and the Peases of Darlington, etc. "Self-Help" arose from lectures he gave in Leeds, particularly one on education of the working classes in 1845. It was published in 1859 , after being refused by a well-known publisher. Nearly half a million copies have been printed and it has appeared in the record number of twenty-six languages. In it and in "Character and Duty" Dr. Smiles showed the British people to the world as very virile and inventive. Although trained as a physician he spent most of his working life as editor and writer of books, and from 1845 until 1866 was secretary of two railway companies. He was largely responsible for the Charing Cross railway and terminuses.
IN addition to the memorial tablet in Zion School, Alderman P. T. Leigh, chairman of the Library Committee, accepted copies of Dr. Smiles's books in bookcase presented by Sir John Murray for the branch library, which has occupied part of Zion School since 1870-the first municipal free library. Sir Walter Smiles, M.P., presented a picture of his grandfather copied from the oil painting in the National Portrait Gallery, to be hung in the civic hall along with other portraits of Leeds worthies. There was an exhibition of relics concerned with Dr. Smiles : copies of first editions of his early books, autographed letters, family bible and portraits, and the Leeds Times of 1838 containing his first speech in Leeds on repeal of the Corn Laws.

\section{Centenary of William Harkness, 1837-I903}

ON December 17, 1837, William Harkness, the American astronomer, was born at Ecclefechan, Scotland, his father being a Presbyterian minister. In 1839 , the family removed to New York, and after attending private schools Harkness entered the University of Rochester and in 1858 took his degree. A short spell of journalism was followed by the study of medicine, and during the Civil War, at intervals, he served as a volunteer surgeon. In 1862, however, he was appointed an assistant to James Melville Gilliss (1865) at the United States Naval Observatory, and it was at Washington that he passed practically the remainder of his life. $\mathrm{He}$ observed the solar eclipses of 1869 and 1870, and in 1871 was appointed one of the original members of the Transit of Venus Commission, being concerned with the preparations for the observation of the transits of 1874 and 1882, and also with the discussion of the results. The transit of 1874 he observed at Hobart, Tasmania. In September, 1894, when new buildings had been erected for the Observatory, regulations were promulgated by the Secretary of the Navy providing for the first time for an "Astronomical Director", who was to "have charge of and to be responsible for the direction, scope, character and preparation for publication of all work purely astronomical, which is performed at the Naval Observatory". To this post Harkness was appointed, the office providing, it was afterwards said, "a maximum of responsibility and a minimum of power". To his duties were added three years later the directorship of the "American Ephemeris and Nautical Almanac". The work, however, proved too much; he broke down and in 1899 retired, being granted the rank of Rear Admiral. He died at Jersey City, N.J., on February 28, 1903. Harkness was one of the founders of the Philosophical Society of Washington and in 1893 served as president of the American Association for the Advancement of Science.

\section{Aborigines of Australia}

THE petition of eighteen hundred Australian aborigines addressed to the King, and asking for representation of their interests in the Federal Parlia. ment (see Nature, Nov. 6, p. 798), whether it attain its end or not, has at least served to direct attention 